Brit. Heart J., 1965, 27, 916.

\title{
CORTICOTROPHIN AND CORTICOSTEROIDS IN THE MANAGEMENT OF ACUTE AND CHRONIC HEART BLOCK
}

\author{
BY \\ CLIVE P. ABER AND E. WYN JONES \\ From the Heart Department, Liverpool Royal Infirmary; and the Liverpool Regional Cardiac Centre
}

Received March 31, 1965

Clinical studies and individual case reports indicate that corticotrophin and corticosteroids frequently help to restore sinus rhythm in acute complete A-V heart block associated with recent myocardial infarction (Prinzmetal and Kennamer, 1954; Phelps and Lindsay, 1957; Aber and Wyn Jones, 1960; Caramelli and Tellini, 1960; Friedberg et al., 1960; Dall and Buchanan, 1962; Dall, 1964). However, the true value of this form of treatment in chronic A-V block is less certain. Tung, Lu, and Fu (1957) and Litchfield, Manley, and Polak (1958) each reported two patients with long-standing block who reverted to sinus rhythm under corticotrophin therapy, and Pay and Waverley (1961) restored sinus rhythm in 5 out of 6 patients with chronic heart block, using oral corticosteroids. On the other hand, Caramelli and Tellini (1960) failed to improve A-V conduction in 10 patients, and in Dall's series (Dall, 1964) only 2 of the 14 patients with long-standing block regained sinus rhythm while receiving "steroid" therapy.

Our experience of corticotrophin and corticosteroids in the treatment of heart block has been less pessimistic. Restoration of sinus rhythm or improved A-V conduction has not only been achieved in most patients with acute heart block, but also in an appreciable number with heart block of considerable duration.

\section{SubJECTS AND METHODS}

Between 1958 and 1964 we studied the effects of corticotrophin (ACTH) and corticosteroids on 36 patients with complete A-V block. These patients form 2 groups.

Group I: 10 patients (6 men and 4 women) with acute heart block (less than 48 hours' duration) following recent myocardial infarction. The mean age was 60 years (range 43-80 years) and the mean duration of heart block before the start of "steroid" therapy was 16.5 hours (range 4-48 hours) (Tables I and III).

Group II: 26 patients ( 8 men and 18 women) with chronic heart block (longer than 1 month's duration). Of these, 11 had undoubted coronary artery disease. In the remaining 15 reliable evidence of coronary artery disease was lacking. The mean age was 61 years (range 34-77 years) and the mean duration of heart block in this group was assessed at 8 months (range 5 weeks to 30 months) (Tables II and III). In several patients accurate assessment of the duration of block was not possible; therefore some of the values recorded in Table II may have been underestimated.

Selection and Management of Patients. Corticotrophin or corticosteroids were given to all patients with acute heart block in association with recent myocardial infarction (Group I). Patients with chronic heart block (Group II) were selected for "steroid" therapy if they were experiencing either incapacitating StokesAdams syncope or were in either right or left heart failure and had failed to respond to more conventional treatment.

The following criteria determined the initial management of these two groups of patients (Tables I and II). 916 
TABLE I

Corticosteroid Therapy: Patients with Acute Heart Block following Recent Myocardial Infarction

\begin{tabular}{|c|c|c|c|c|c|c|c|}
\hline \multicolumn{3}{|c|}{$\begin{array}{l}\text { Case No., sex, } \\
\text { and age (yr.) }\end{array}$} & \multirow{2}{*}{$\begin{array}{l}\text { Electrocardiogram } \\
\text { Complete block }\end{array}$} & \multirow{3}{*}{\begin{tabular}{l}
\multicolumn{1}{c}{$\begin{array}{c}\text { Clinical } \\
\text { picture }\end{array}$} \\
$\begin{array}{l}\text { Stokes-Adams } \\
\text { syncope } \\
\text { Shock }\end{array}$
\end{tabular}} & \multirow{2}{*}{$\begin{array}{c}\begin{array}{c}\text { Duration } \\
\text { of block }\end{array} \\
2 \mathrm{hr} .\end{array}$} & \multirow{4}{*}{$\begin{array}{c}\begin{array}{c}\text { Initial } \\
\text { therapy }\end{array} \\
\text { Hydrocortisone } \\
400 \text { mg. } \\
\text { Hydrocortisone } \\
300 \mathrm{mg} \text {. } \\
\text { Hydrocortisone } \\
300 \text { mg. and } \\
\text { pacemaker }\end{array}$} & \multirow{4}{*}{\begin{tabular}{l}
\multicolumn{1}{c}{ Response } \\
AF; persistent \\
complete block \\
SR in $12 \mathrm{hr}$. \\
SR in $9 \mathrm{hr}$.
\end{tabular}} \\
\hline 1 & & 80 & & & & & \\
\hline 2 & F & 64 & $\begin{array}{l}\text { Complete block; } \\
\text { posterior infarct }\end{array}$ & & $<2 \mathrm{hr}$ & & \\
\hline 3 & $\mathbf{F}$ & 69 & $\begin{array}{l}\text { Complete block; } \\
\text { antero-septal } \\
\text { infarct and } \\
\text { RBBB }\end{array}$ & $\begin{array}{l}\text { Stokes-Adams } \\
\text { syncope }\end{array}$ & $1 \mathrm{hr}$. & & \\
\hline 4 & $\mathbf{M}$ & 52 & $\begin{array}{l}\text { Complete block } \\
\text { and RBBB }\end{array}$ & LV failure & 2 dy. & $\begin{array}{l}\text { Prednisolone } 20 \\
\text { mg. b.i.d. }\end{array}$ & $\mathrm{SR}$ in $12 \mathrm{hr}$. \\
\hline 5 & $\mathbf{M}$ & 56 & Complete block & Acute LV failure & $24 \mathrm{hr}$. & $\begin{array}{l}\text { Hydrocortisone } \\
400 \mathrm{mg} \text {. }\end{array}$ & $\begin{array}{l}\text { 2:1 A-V block on } \\
\text { 3rd day; AF and } \\
\text { resolution of A- } \\
V \text { block on 4th } \\
\text { day }\end{array}$ \\
\hline 6 & $\mathbf{M}$ & 60 & Complete block & $\begin{array}{l}\text { Stokes-Adams } \\
\text { syncope and LV } \\
\text { failure }\end{array}$ & $12 \mathrm{hr}$. & $\begin{array}{l}\text { Prednisolone } 10 \\
\text { mg. t.i.d. }\end{array}$ & $\mathrm{SR}$ in $14 \mathrm{hr}$. \\
\hline 7 & $\mathbf{M}$ & 57 & $\begin{array}{l}\text { Complete block } \\
\text { and RBBB }\end{array}$ & LV failure & $2 \mathrm{dy}$. & $\begin{array}{l}\text { Hydrocortisone } \\
400 \mathrm{mg} \text {. }\end{array}$ & $\begin{array}{l}\text { AF with resolu- } \\
\text { tion of } A-V \\
\text { block in } 14 \mathrm{hr}\end{array}$ \\
\hline 8 & $\mathbf{F}$ & 62 & $\begin{array}{l}\text { Complete block } \\
\text { and LBBB }\end{array}$ & LV failure & $12 \mathrm{hr}$. & $\begin{array}{l}\text { Hydrocortisone } \\
600 \mathrm{mg} \text {. }\end{array}$ & $\mathrm{SR}$ in $12 \mathrm{hr}$. \\
\hline 9 & $\mathbf{F}$ & 43 & $\begin{array}{l}\text { Complete block } \\
\text { and RBBB }\end{array}$ & $\begin{array}{l}\text { Stokes-Adams } \\
\text { syncope }\end{array}$ & $12 \mathrm{hr}$. & $\begin{array}{l}\text { Hydrocortisone } \\
400 \mathrm{mg} \text {. and } \\
\text { pacemaker }\end{array}$ & $\mathrm{SR}$ in $10 \mathrm{hr}$. \\
\hline 10 & $\mathbf{M}$ & 60 & Complete block & $\begin{array}{l}\text { Stokes-Adams } \\
\text { syncope }\end{array}$ & $4 \mathrm{hr}$. & $\begin{array}{l}\text { Hydrocortisone } \\
300 \mathrm{mg} \text {. }\end{array}$ & $\mathrm{SR}$ in $12 \mathrm{hr}$. \\
\hline
\end{tabular}

RBBB, right bundle-branch block; LV, left ventricle; AF, atrial fibrillation; SR, sinus rhythm.

(i) Corticotrophin was used if there was neither shock nor severe right or left heart failure. Initial dosage 30-40 units twice a day.

(ii) Hydrocortisone hemisuccinate was used (usually intravenously) in the presence of shock. Initial dosage 300-600 mg. over the first 24 hours, then 150-300 mg. daily for 4-5 days.

(iii) Oral prednisolone was given to patients in either right or left heart failure. Initial dosage 10-15 mg. three times a day. Corticotrophin and corticosteroids were gradually withdrawn either within 24-48 hours of return of sinus rhythm or on the 10th-12th day if no change in heart rhythm had occurred by this time. Maintenance oral corticosteroids were advised for a minimum of 3 months when sinus rhythm had returned or A-V conduction had improved in patients in Group II. Maintenance therapy was not advised in Group I.

Supplementary potassium chloride ( $1 \mathrm{~g}$. twice or three times a day) was usually given to the patients while they were receiving either corticotrophin or corticosteroids.

Serial conventional 12-lead electrocardiograms were recorded throughout the treatment period, as indicated by the clinical progress of each patient. Serum electrolyte measurements were also made throughout the treatment period.

Note: (i) When patients in Group II had been receiving more conventional treatment (ephedrine, isoprenaline, or dipyridamole) before commencement of "steroid" therapy, this was continued during the initial treatment period.

(ii) Two patients (Cases 3 and 9) had catheter pacemakers inserted into their right ventricles immediately after beginning "steroid" therapy.

\section{RESULTS}

$A-V$ Conduction. Sinus rhythm was restored in 21 patients $(58 \%) ; 7$ of them $(70 \%)$ were in Group I and $14(54 \%)$ were in Group II. 
TABLE II

Steroid Therapy in Patients with Chronic Heart Block

\begin{tabular}{|c|c|c|c|c|c|c|c|}
\hline \multicolumn{3}{|c|}{$\begin{array}{l}\text { Case No., sex, } \\
\text { and age (yr.) }\end{array}$} & \multirow{2}{*}{$\begin{array}{l}\text { Electrocardiogram } \\
\text { Complete block } \\
\text { and RBBB }\end{array}$} & \multirow{2}{*}{$\begin{array}{c}\begin{array}{c}\text { Clinical } \\
\text { picture }\end{array} \\
\begin{array}{c}\text { Stokes-Adams } \\
\text { syncope and } \\
\text { CAD }\end{array}\end{array}$} & \multirow{2}{*}{$\begin{array}{c}\begin{array}{c}\text { Duration } \\
\text { of block }\end{array} \\
3 \mathrm{mth} .\end{array}$} & \multirow{2}{*}{$\frac{\begin{array}{c}\text { Initial } \\
\text { therapy }\end{array}}{\text { ACTH } 30 \mathrm{u} .}$} & \multirow{2}{*}{$\frac{\text { Response }}{\text { SR in } 10 \text { dáys }}$} \\
\hline 11 & $\mathbf{F}$ & 71 & & & & & \\
\hline 12 & $\mathbf{F}$ & 67 & Complete block & $\begin{array}{l}\text { Stokes-Adams } \\
\text { syncope and } \\
\text { CAD }\end{array}$ & $3 \mathrm{mth}$. & $\underset{\text { b.i.d. }}{\text { ACTH }} 30 \mathrm{u}$. & $\begin{array}{l}\text { 2:1 A-V block in } \\
13 \text { days }\end{array}$ \\
\hline 13 & $\mathbf{F}$ & 66 & Complete block & $\begin{array}{l}\text { Stokes-Adams } \\
\text { syncope }\end{array}$ & 12 mth. & $\underset{\text { b.i.d. }}{\text { ACTH }} 40$ u. & SR in 6 days \\
\hline 14 & $\mathbf{M}$ & 58 & $\begin{array}{l}\text { Complete block } \\
\text { and LBBB }\end{array}$ & $\begin{array}{l}\text { Stokes-Adams } \\
\text { syncope }\end{array}$ & $6 \mathrm{mth}$. & ACTH $40 \mathrm{u}$. & $\begin{array}{l}2: 1 \text { A-V block in } \\
7 \text { days }\end{array}$ \\
\hline 15 & $\mathbf{M}$ & 71 & $\begin{array}{l}\text { Complete block } \\
\text { and RBBB }\end{array}$ & $\begin{array}{l}\text { Left and right } \\
\text { heart failure and } \\
\text { CAD }\end{array}$ & $>2 \mathrm{mth}$ & $\begin{array}{l}\text { Prednisolone } \\
10 \text { mg. b.i.d. }\end{array}$ & $S R$ in 2 days \\
\hline 16 & $\mathbf{M}$ & 45 & $\begin{array}{l}\text { Complete block } \\
\text { and LBBB }\end{array}$ & $\begin{array}{l}\text { Left and right } \\
\text { heart failure and } \\
\text { CAD }\end{array}$ & 2 mth. & $\begin{array}{l}\text { Prednisolone } \\
10 \text { mg. t.i.d. }\end{array}$ & No change \\
\hline 17 & $\mathbf{F}$ & 55 & $\begin{array}{l}\text { Complete block } \\
\text { and RBBB }\end{array}$ & $\begin{array}{l}\text { Stokes-Adams } \\
\text { syncope }\end{array}$ & 6 mth. & $\begin{array}{l}\text { ACTH } 40 \text { u. } \\
\text { b.i.d. }\end{array}$ & SR in 9 days \\
\hline 18 & $\mathbf{F}$ & 51 & $\begin{array}{l}\text { Complete block } \\
\text { and RBBB }\end{array}$ & $\begin{array}{l}\text { Stokes-Adams } \\
\text { syncope and } \\
\text { CAD }\end{array}$ & 6 wk. & $\begin{array}{l}\text { ACTH } 40 \mathrm{u} . \\
\text { b.i.d. }\end{array}$ & SR in 9 days \\
\hline 19 & $\mathbf{F}$ & 69 & Complete block & Pernicious anæmia & 2 yr. & $\begin{array}{c}\text { ACTH } 30 \mathrm{u} . \\
\text { b.i.d. }\end{array}$ & SR in 4 days \\
\hline 20 & $\mathbf{F}$ & 75 & $\begin{array}{l}\text { Complete block } \\
\text { and RBBB }\end{array}$ & CAD & 5 wk. & $\begin{array}{l}\text { ACTH } 30 \mathrm{u} . \\
\text { b.i.d. }\end{array}$ & SR in 3 days \\
\hline 21 & $\mathbf{F}$ & 56 & Complete block & CAD & $4 \mathrm{mth}$. & $\begin{array}{l}\text { ACTH } 40 \mathrm{u} . \\
\text { b.i.d. }\end{array}$ & No change \\
\hline 22 & $\mathbf{F}$ & 64 & Complete block & $\begin{array}{l}\text { Stokes-Adams } \\
\text { syncope }\end{array}$ & $6 \mathrm{mth}$. & $\begin{array}{l}\text { ACTH } 40 \text { u. } \\
\text { b.i.d. }\end{array}$ & SR in 4th week \\
\hline 23 & $\mathbf{F}$ & 34 & Complete block & Pneumonia, VSD & $6 \mathrm{mth}$. & $\underset{\text { b.i.d. }}{\text { ACTH }} 30 \mathrm{u}$. & No change \\
\hline 24 & F & 73 & $\begin{array}{l}\text { Complete block } \\
\text { LV hypertrophy }\end{array}$ & $\begin{array}{l}\text { Stokes-Adams } \\
\text { syncope and left } \\
\text { heart failure and } \\
\text { CAD }\end{array}$ & $>1$ mth. & $\begin{array}{l}\text { Prednisolone } \\
10 \text { mg. t.d.s. }\end{array}$ & No change \\
\hline 25 & $\mathbf{F}$ & 64 & $\begin{array}{l}\text { Complete block } \\
\text { and RBBB }\end{array}$ & $\begin{array}{l}\text { Stokes-Adams } \\
\text { syncope and } \\
\text { congestive heart } \\
\text { failure }\end{array}$ & $2 \frac{1}{2} \mathrm{yr}$. & $\begin{array}{l}\text { Prednisolone } \\
10 \text { mg. t.d.s. }\end{array}$ & SR in 3rd week \\
\hline 26 & $\mathbf{F}$ & 66 & Complete block & $\begin{array}{l}\text { Stokes-Adams } \\
\text { syncope and } \\
\text { CAD }\end{array}$ & $>2$ mth. & $\begin{array}{l}\text { ACTH } 40 \mathrm{u} . \\
\text { b.i.d. }\end{array}$ & No change \\
\hline 27 & $\mathbf{M}$ & 58 & $\begin{array}{l}\text { 2:1 A-V block and } \\
\text { complete block } \\
\text { and RBBB }\end{array}$ & $\begin{array}{l}\text { Stokes-Adams } \\
\text { syncope }\end{array}$ & $>18$ mth. & $\underset{\text { b.i.d. }}{\text { ACTH }} 40 \mathrm{u}$. & No change \\
\hline 28 & $\mathbf{F}$ & 63 & $\begin{array}{l}\text { Complete block } \\
\text { and RBBB }\end{array}$ & $\begin{array}{l}\text { “Tiredness" and } \\
\text { Stokes-Adams } \\
\text { syncope }\end{array}$ & 9 mth. & $\underset{\text { b.i.d. }}{\text { ACTH }} 30 \mathrm{u.}$ & $\mathrm{SR}$ in 10 days \\
\hline 29 & $\mathbf{M}$ & 46 & $\begin{array}{l}\text { Complete block, } \\
\text { AF, RBBB }\end{array}$ & $\begin{array}{l}\text { Stokes-Adams } \\
\text { syncope }\end{array}$ & $>9$ mth. & $\begin{array}{l}\text { Hydrocortisone } \\
300 \mathrm{mg} \text {. }\end{array}$ & $\begin{array}{l}\text { Abolition of A-V } \\
\text { block in } 2 \text { days }\end{array}$ \\
\hline 30 & $\mathbf{M}$ & 40 & $\begin{array}{l}\text { Complete block, } \\
\text { AF, RBBB }\end{array}$ & $\begin{array}{l}\text { Stokes-Adams } \\
\text { syncope }\end{array}$ & 2 mth. & $\begin{array}{l}\text { Prednisolone } \\
10 \text { mg. t.i.d. }\end{array}$ & No change \\
\hline 31 & $\mathbf{M}$ & 53 & $\begin{array}{l}\text { Complete block } \\
\text { and RBBB }\end{array}$ & $\begin{array}{l}\text { Stokes-Adams } \\
\text { syncope }\end{array}$ & 9 mth. & $\begin{array}{l}\text { Prednisolone } \\
10 \text { mg. q.i.d. }\end{array}$ & $\begin{array}{l}2: 1 \text { A-V block in } \\
4 \cdot \text { days }\end{array}$ \\
\hline 32 & $\mathbf{F}$ & 69 & Complete block & $\begin{array}{l}\text { Stokes-Âdams } \\
\text { syncope }\end{array}$ & $2 \mathrm{yr}$. & $\begin{array}{l}\text { Prednisolone } \\
10 \mathrm{mg} \text {. t.i.d. }\end{array}$ & No change \\
\hline 33 & $\mathbf{M}$ & 77 & $\begin{array}{l}\text { Complete block } \\
\text { and RBBB }\end{array}$ & CAD & 4 mth. & $\begin{array}{l}\text { Prednisolone } \\
10 \mathrm{mg} \text {. t.i.d. }\end{array}$ & SR in 2 days \\
\hline 34 & $\mathbf{F}$ & 63 & $\begin{array}{l}\text { Complete block } \\
\text { and LBBB }\end{array}$ & CAD & $>4$ mth. & $\begin{array}{l}\text { ACTH } 30 \mathrm{u} \text {. } \\
\text { b.i.d. }\end{array}$ & SR in 7 days \\
\hline
\end{tabular}


TABLE II-continued

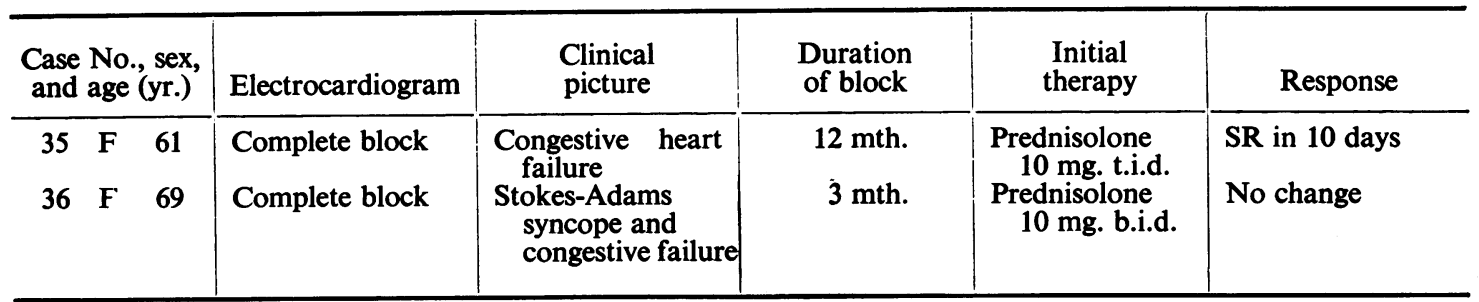

RBBB, right bundle-branch block; LBBB, left bundle-branch block; CAD, coronary artery disease; $A F$, atrial fibrillation; SR, sinus rhythm.

TABLE III

Response of Acute and Chronic Heart Block to Corticotrophin and Corticosteroid Therapy in 10 Patients IN Group I, AND 26 PATIENTS IN Group II

\begin{tabular}{|c|c|c|c|}
\hline & Group & No. & $\begin{array}{c}\text { Mean duration of A-V block } \\
\text { (range) }\end{array}$ \\
\hline Resolution or improved A-V conduction & $\left\{\begin{array}{l}\text { I } \\
\text { II }\end{array}\right.$ & $\begin{array}{l}9(90 \%) \\
17(65 \%)\end{array}$ & $\begin{array}{c}16.5 \mathrm{hr} . \\
(4-48 \mathrm{hr} .) \\
8 \mathrm{mth} . \\
\text { (5 wk. }-30 \mathrm{mth} .)\end{array}$ \\
\hline No response & $\left\{\begin{array}{l}\text { I } \\
\text { II }\end{array}\right.$ & $\begin{array}{l}1(10 \%) \\
9(35 \%)\end{array}$ & $\begin{array}{c}2 \mathrm{hr} . \\
7 \mathrm{mth} . \\
(>1 \mathrm{mth} .-2 \mathrm{yr} .)\end{array}$ \\
\hline
\end{tabular}

Improved A-V conduction, as evidenced by the development of 2:1 A-V block in place of complete A-V block (Fig. 1), was achieved in a further 3 patients (Cases 12, 14, and 31) in Group II (Table II).

Two patients in Group I (Cases 5 and 7) developed uncontrolled atrial flutter-fibrillation on resolution of their A-V block (Fig. 2) and subsequently required full digitalization in order to control the ventricular rate. Similarly, one patient (Case 29) from Group II, who was in atrial fibrillation with complete A-V block before "steroid" therapy, developed an uncontrolled ventricular response once the A-V block had resolved (Fig. 3). In contrast, another patient (Case 1) developed atrial fibrillation while receiving corticosteroids, but his A-V block remained unchanged.

No alteration in A-V conduction was observed in 10 patients $(28 \%)$ after one or more courses of corticotrophin or corticosteroid therapy. One of these patients was in Group l $(10 \%)$ whereas the other 9 were in Group II $(35 \%)$. Despite lack of improvement in A-V conduction, Stokes-Adams syncope, when present, was usually abolished during the treatment period, and occasionally an increase in both atrial and ventricular rates was also noted without alteration in A-V conduction (Fig. 4).

Duration of Block. In both acute and chronic heart block (Groups I and II), it did not appear that the time interval between the onset of the conduction abnormality and the commencement of "steroid" therapy influenced the chance of restoring sinus rhythm, though the success rate in Group II was substantially less than in Group I. However, successful reversion to sinus rhythm or improvement in A-V conduction was achieved in several patients with conduction abnormalities of a year or longer (Cases 13, 19, 25, and 35, and Tables I, II, and III).

Response Time. Rapid improvement in A-V conduction was usual in Group I, where 8 of the 9 patients who responded satisfactorily did so within 15 hours of commencing treatment. However, $3 \mathrm{M}$ 
A

(29.9.59)

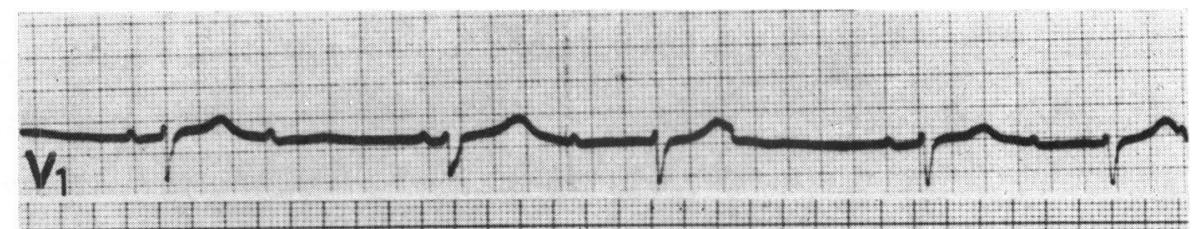

B

(12.10.59)

\section{$V_{1}$}

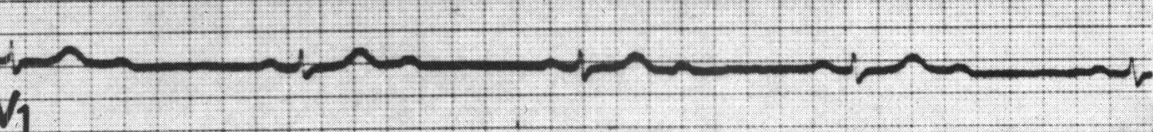

FiG. 1.-Case 12. (A) Complete A-V block before corticotrophin therapy (ventricular rate 50 a minute). (B) Development of 2:1 block after 13 days of corticotrophin therapy (ventricular rate 40 a minute).

A

(27.2.62)

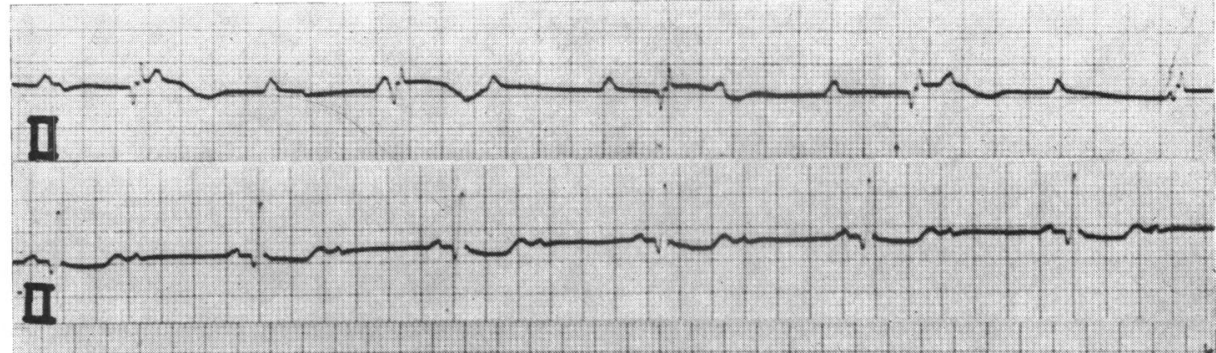

C

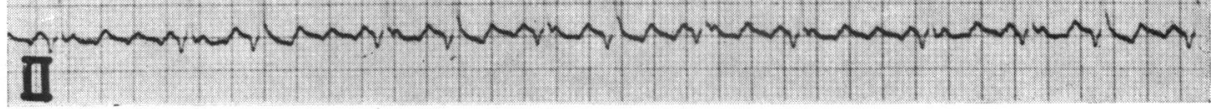

FIG. 2.-Case 5. (A) Complete A-V block before steroid therapy. (B) Development of 2:1 block on 3rd day of steroid therapy. (C) Uncontrolled atrial flutter/fibrillation and resolution of A-V block on 4th day of steroid therapy.

A

29.10 .63

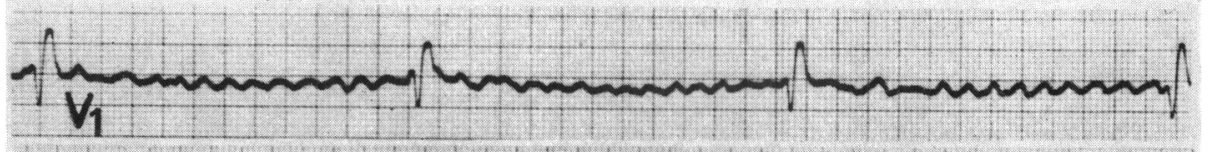

B

(31.10.63)

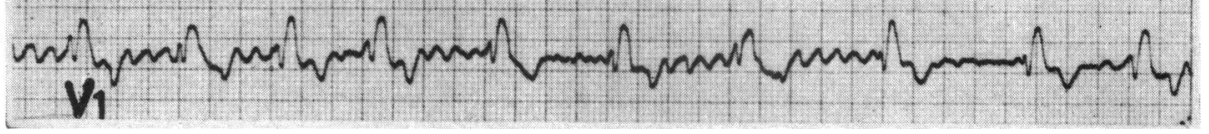

FIG. 3.-Case 29. (A) Atrial fibrillation and complete A-V block before corticosteroid therapy. (B) Resolution of A-V block with uncontrolled ventricular response after 2 days of corticosteroid therapy.

A

(27.11.61)

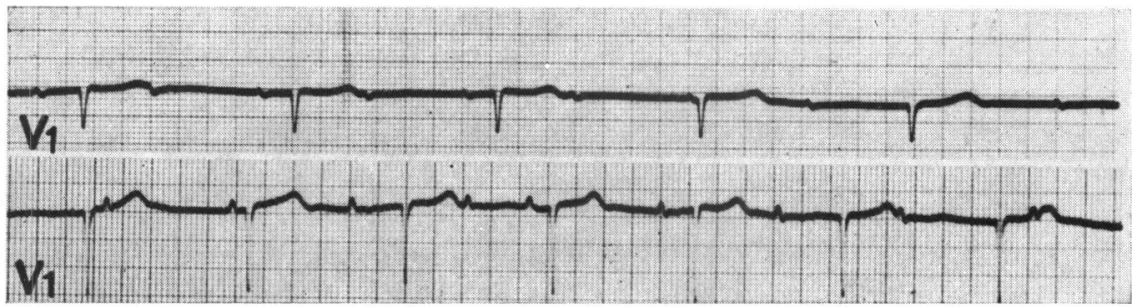

Fig. 4.-Case 32. (A) Complete A-V block with ventricular rate of 50 a minute and atrial rate of 72 a minute before corticosteroid therapy. (B) Increase of ventricular rate to 62 a minute and of atrial rate to 90 a minute after 9 th day of corticosteroid therapy; persistence of complete A-V block. 
in one patient (Case 5), complete resolution of heart block was only achieved on the 4th day, though 2:1 block had been observed on the previous day (Fig. 2, and Table I).

In Group II, the onset of sinus rhythm or improvement in A-V conduction usually occurred within 10 days of commencing treatment, though 2 patients (Cases 22 and 25) failed to respond until the 4th and 3rd weeks, respectively. By this time "steroid" therapy was gradually being withdrawn, and in both instances a long-acting oral isoprenaline preparation (saventrin) had been prescribed (Table II).

Unusual Electrocardiographic Changes. During this study we occasionally observed alterations in the $\mathrm{T}$ wave configuration and $\mathrm{Q}-\mathrm{T}$ interval in the electrocardiogram, despite lack of improvement in A-V conduction (Cases 1, 21, 24, 26, 27, 30, and 36). These electrocardiographic disturbances consisted of deepening and widening of the $\mathrm{T}$ waves with marked prolongation of the Q-T interval, yet no significant alteration of the QRS complex was noted (Fig. 5). With one exception (Case 30), these changes occurred without significant alteration in the ventricular rate, blood pressure, or serum electrolytes, and resolved on withdrawal of "steroid" therapy (Aber and Wyn Jones, 1965). In Case 30, however, this type of electrocardiographic pattern was accompanied by marked hypokalæmia (serum potassium $2.0 \mathrm{mEq} / \mathrm{l}$.) and resolved after correction of the serum potassium level. Only in this patient was the electrocardiographic disturbance accompanied by clinical deterioration; indeed, most patients at this time were showing both subjective and objective improvement.

Follow-up. To date, 4 of the 9 patients in Group I who benefited from "steroid" therapy have died. One (Case 3) ruptured her right ventricle at the site of a recent myocardial infarction (anteroseptal) 4 days after sinus rhythm had returned. The remaining 5 patients in this group are still alive and have had no further disturbances of $\mathrm{A}-\mathrm{V}$ conduction so far as we are aware.

Of the 17 patients in Group II in whom the A-V block had resolved or improved during "steroid" therapy, 7 experienced sustained benefit for at least 2 years. Two (Cases 17 and 25) were still in sinus rhythm 3 or more years later; and in one (Case 25), sinus rhythm has persisted for 6 years. One patient (Case 22) continued in sinus rhythm for 8 months before development of 2:1 A-V block. Here sinus rhythm was again rapidly restored with corticotrophin (Fig. 6), and normal A-V conduction was present more than 10 months later. In two patients (Cases 13 and 17) complete A-V block returned after 3 and 4 years respectively, and failed to improve with further courses of corticotrophin and corticosteroids. Both patients have since been satisfactorily controlled by implantation of permanent pacemakers. A further patient (Case 34) reverted to complete A-V block within one month of regaining sinus rhythm despite maintenance steroid therapy, and refused further admission to hospital.

To date, 3 of the 17 patients from Group II, who benefited from "steroid" therapy, have died. One (Case 11) died suddenly 9 months after return of sinus rhythm; another (Case 12) died in complete A-V block 3 months after reversion to sinus rhythm, and a further patient (Case 29) died in complete A-V block shortly after an attempt had been made to convert his atrial fibrillation to sinus rhythm with quinidine: necropsy revealed chronic rheumatic mitral incompetence. No follow-up observations were made in one patient (Case 31).

\section{DiscusSION}

Our experience endorses that of others (Caramelli and Tellini, 1960; Friedberg et al., 1960; Dall and Buchanan, 1962; Dall, 1964) who have observed rapid resolution of acute heart block in patients who have had recent myocardial infarction, following intravenous corticosteroid therapy. However, since spontaneous restoration of sinus rhythm is common and sometimes equally rapid under these circumstances, the true effectiveness of corticosteroids is difficult to assess (Penton, Miller, and Levine, 1956; Gilchrist, 1958; Zoob and Shirley Smith, 1963). Furthermore the need for constant clinical vigil while treating this group of patients is emphasized by (i) the occasional development of uncontrolled atrial fibrillation (or flutter) rather than return to sinus rhythm on 


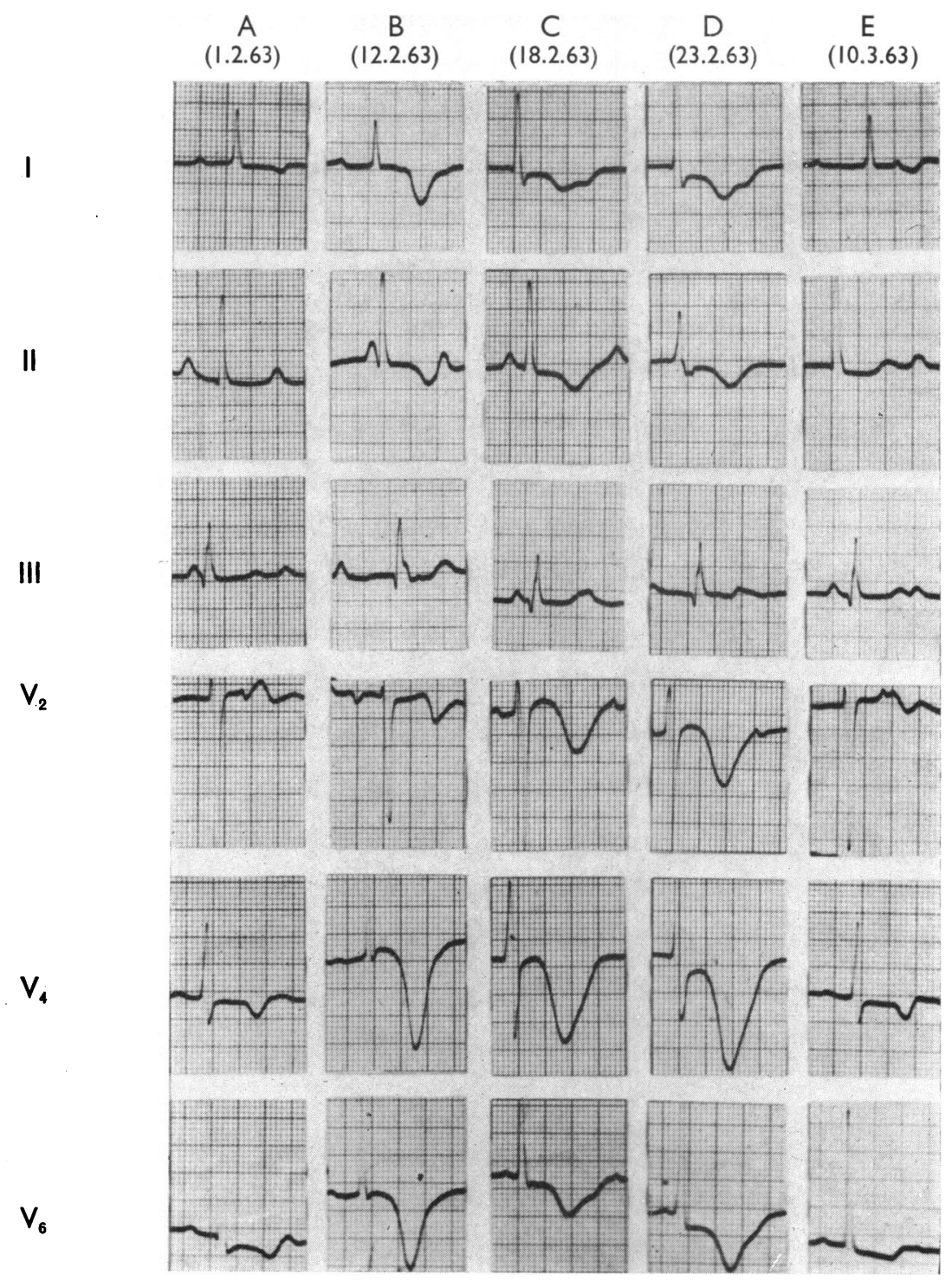

FIG. 5.-Case 21. (A) The QRS and T wave pattern before corticotrophin therapy. Complete A-V block with upright $T$ waves in leads II, III, and V2, and inverted T waves in leads I, V4, and V6. (B, C, and D) Progressive enlargement, inversion, and widening of the T waves in leads I, V4, and V6 with inversion of $T$ waves in leads II and V2. No changes in the QRS complex. (E) Return to the pre-therapy pattern two weeks after withdrawal of corticotrophin.

resolution of the A-V block; and (ii) the likelihood that some patients will still require "pacing" for a short time before sinus rhythm returns (Friedberg et al., 1960).

Sustained resolution of long-standing A-V block in a substantial number of patients in Group II, though very satisfactory, contrasts sharply with the poor response observed by others when managing this type of clinical problem (Caramelli and Tellini, 1960; Dall and Buchanan, 1962; Dall, 1964). 


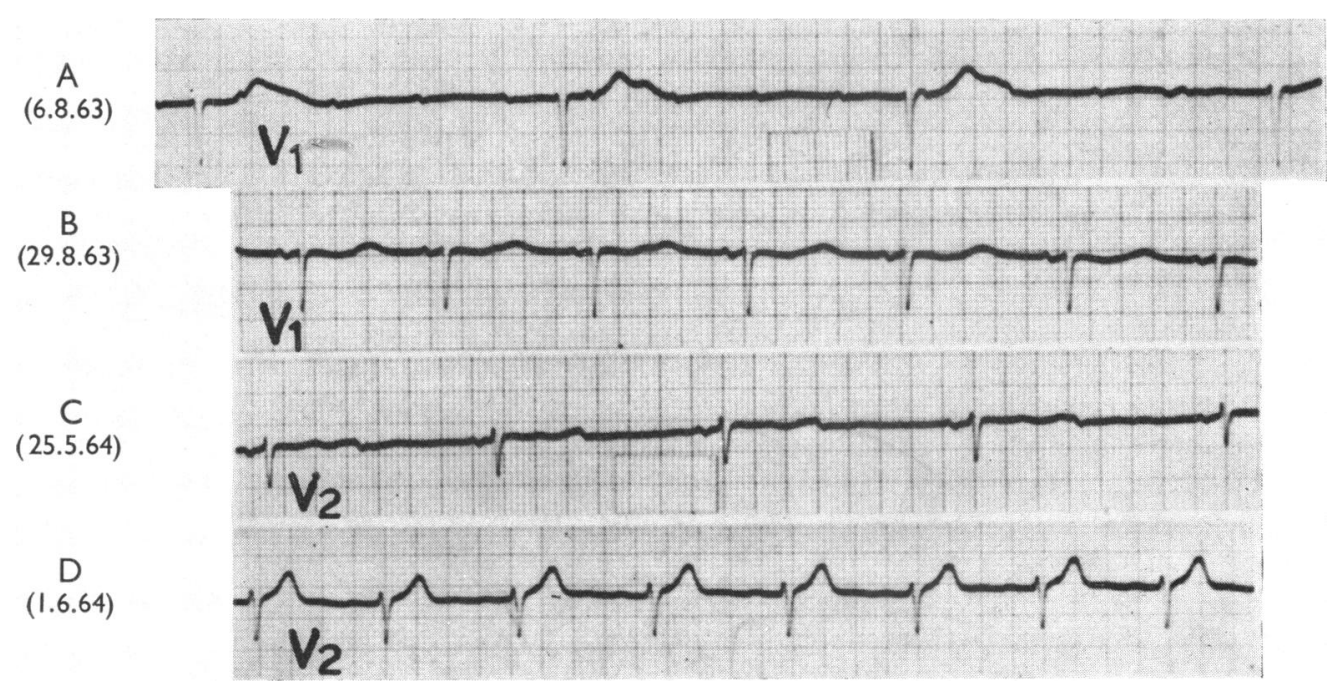

FIG. 6.-Case 22. (A) Complete A-V block before first course of corticotrophin. (B) Return of sinus rhythm on 23rd day of therapy, during withdrawal of corticotrophin. (C) Development of 2:1 block 8 months after return of sinus rhythm. (D) Sinus rhythm rapidly restored with further course of corticotrophin.

Therefore, a trial with corticotrophin or corticosteroids seems to be worth while in patients disabled with chronic A-V block, not only because there is a reasonable chance of restoring sinus rhythm but also because incapacitating Stokes-Adams syncope can be satisfactorily controlled by this form of treatment, even though A-V conduction is not improved (Aber and Wyn Jones, 1960; Friedberg et al., 1960; Pay and Waverley, 1961; Verel, Mazurkie, and Rahman, 1963).

Selection of the most effective "steroid" preparation and the correct dosage remains more speculative. As the result of our initial experience (Aber and Wyn Jones, 1960), we have generally continued to use corticotrophin in uncomplicated chronic A-V block. On the other hand, if there is evidence of either severe congestive or left heart failure in this type of patient, we have usually prescribed prednisolone to avoid undue risk of further fluid and salt retention. Both preparations have proved effective, but the present series is too small to allow satisfactory statistical comparison. However, Litchfield et al. (1958) report success with corticotrophin, when large doses of cortisone (200 mg. daily) and prednisolone (60 mg. daily) had previously failed to improve A-V conduction.

Caramelli and Tellini (1960) and Dall (1964) consider that in chronic A-V block sinus rhythm is unlikely to return after the fourth day of "steroid" therapy, and therefore it is unnecessary and perhaps unwise to continue with this form of treatment for longer periods. In contrast, our results indicate that it is often both necessary and desirable to continue corticotrophin and corticosteroid administration in large doses for at least 10 days, since in chronic block, restoration of sinus rhythm was frequently not achieved until the second week of therapy or even later while "steroids" were being withdrawn. In the latter circumstance, alternative more conventional treatment had been started, so that unfortunately it is impossible to be certain which drug was effective, or whether, indeed, one was complementary or synergistic to the other. Perhaps at this time intracellular/ extracellular electrolyte flux at the A-V node, as a consequence of "steroid" therapy, had effected an incomplete augmentation of A-V conduction which was subsequently further improved by the sympathomimetic drug.

The manner by which corticotrophin and corticosteroids improve atrio-ventricular conduction in chronic heart block remains uncertain. The relatively high proportion of women and the fre- 
quent absence of reliable evidence of coronary artery disease in Group II, along with accumulating data that indicate that A-V block is quite common without either clinical or histological coronary artery disease, suggest that other ætiological factors must be considered. Campbell (1944) found evidence of ischæmic heart disease in only 17 of his 74 patients, in 23 of whom no cause for the block was evident. Chronic rheumatic heart disease in association with a complete A-V block which responded to "steroid" therapy is reported in the present series (Case 29), and has been previously recorded by Litchfield et al. (1958). In addition, Zoob and Shirley Smith (1963) have demonstrated scattered foci of myocardial fibrosis, occasionally associated with lymphocytic infiltration of the myocardium, in cases of complete heart block without coronary artery disease. If, indeed, some form of chronic "inflammatory" reaction was present in complete heart block, it would be reasonable to accept improvement in A-V conduction with corticosteroids and corticotrophin, without having to postulate a "facilitating" effect on nodal activity (Lown et al., 1955). Similarly, it would be easier to understand the return of A-V block on withdrawal of "steroid" therapy in some patients and the critical dependence on maintenance therapy in others (Friedberg et al., 1960; Pay and Waverley, 1961 ; Verel et al., 1963).

The significance of the "steroid" induced $\mathrm{T}$ wave changes in the electrocardiograms of some patients whose block remained refractory to therapy also remains uncertain. Since one patient had similar electrocardiographic changes in association with hypokalæmia, it is again tempting to suggest that disturbance of local electrolyte flux (potassium: sodium) in areas of damaged myocardium may be responsible (Aber and Wyn Jones, 1965).

Fortunately, previous administration of either corticotrophin or corticosteroids does not seem to impair the subsequent response to permanent artificial cardiac pacing. It may, indeed, postpone the need for this more radical, and not as yet foolproof, technique for two to three years (Davies and Siddons, 1965).

\section{SUMMARY}

The value of corticotrophin and corticosteroids in the management of 36 patients with acute and chronic heart block has been described. Complete or partial resolution of the heart block was obtained in 9 out of $10(90 \%)$ patients with acute $\mathrm{A}-\mathrm{V}$ block following myocardial infarction; and in 17 of the $26(60 \%)$ patients with chronic A-V block. In nearly half of these patients the improved conduction was maintained for more than two years.

In other patients, despite failure to improve A-V conduction, there was striking clinical benefit. Abolition of Stokes-Adams attacks was habitually observed during treatment.

Possible mechanisms of the therapeutic action of "steroids" in heart block are discussed.

We wish to thank our colleagues at the Liverpool Royal Infirmary and the Liverpool Regional Cardiac Centre for the opportunity of seeing their patients.

\section{REFERENCES}

Aber, C. P., and Wyn Jones, E. (1960). Complete heart block treated with corticotrophin and corticosteroid. Brit. Heart J., 22, 723.

- , and $-(1965)$. Steroid-induced T wave changes in heart block. Brit. Heart J., $27,56$.

Campbell, M. (1944). Complete heart block. Brit. Heart J., 6, 69.

Caramelli, Z., and Tellini, R. R. (1960). Treatment of atrioventricular block with prednisone. Amer. J. Cardiol., $5,263$.

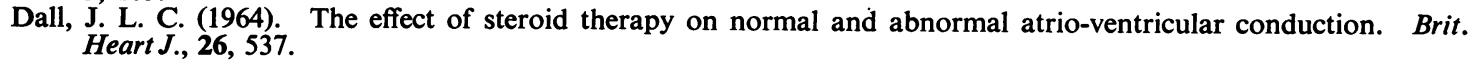

, and Buchanan, J. (1962). Steroid therapy in heart-block following myocardial infarction. Lancet, 2, 8.
Davies, J. G., and Siddons, H. (1965). Experience with implanted pacemakers: Technical considerations. Thorax, 20, 128 .

Friedberg, C. K., Kahn, M., Scheuer, J., Bleifer, S., and Dack, S. (1960). Adams-Stokes syndrome associated with chronic heart block. Treatment with corticosteroids. J. Amer. med. Ass., 172, 1146.

Gilchrist, A. R. (1958). Clinical aspects of high-grade heart-block. Scot. med. J., 3, 53. 
Litchfield, J. W., Manley, K. A., and Polak, A. (1958). Stokes-Adams attacks treated with corticotrophin. Lancet, 1, 935.

Lown, B., Arons, W. L., Ganong, W. F., Vazifdar, J. P., and Levine, S. A. (1955). Adrenal steroids and auriculoventricular conduction. Amer. Heart J., 50, 760.

Pay, B. W., and Waverley (1961). Adrenocortical steroids in intermittent heart-block. Brit. med. J., $2,139$.

Penton, G. B., Miller, H., and Levine, S. A. (1956). Some clinical features of complete heart block. Circulation, 13, 801.

Phelps, M. D., and Lindsay, J. D. (1957). Cortisone in Stokes-Adams disease secondary to myocardial infarction. New Engl. J. Med., 256, 204.

Prinzmetal, M., and Kennamer, R. (1954). Emergency treatment of cardiac arrhythmias. J. Amer. med. Ass., 154, 1049.

Tung, C. L., Lu, S. T., and Fu, H. H. (1957). Corticotropin (ACTH) therapy of Morgagni-Adams-Stokes syndrome in patients with complete heart block. Chin. med. J., 75, 181.

Verel, D., Mazurkie, S. J., and Rahman, F. (1963). Prednisone in the treatment of Adams-Stokes attacks. Brit. Heart J., 25, 709.

Zoob, M., and Shirley Smith, K. (1963). The ætiology of complete heart-block. Brit. med. J., $2,1149$. 